\title{
China Pakistan Economic Corridor
}

\author{
Muhammad Aon \\ University of Management and Technology Lahore \\ Muhammad Amin \\ University of Management and Technology Lahore \\ Ayesha Akram \\ University of Management and Technology Lahore
}

\begin{abstract}
The China Pakistan Economic Corridor (CPEC), a project of China's Belt and Road Initiative (BRI), is being seen as a game changer for Pakistan that will connect china's south-western region Xinxiang, Tibet and Qinghai with Pakistan's southern part particularly Gwadar. This project will brings economic development and prosperity for whole south Asia. CPEC is a ready-made solution to Pakistan's many economic troubles. this economic corridor will run about $2700 \mathrm{~km}$ from Gwadar to Kashgar By CPEC Pakistan will develop Gwadar port, link it to Karachi and Lahore through motorways and through karakaram highway to Kashgar in south-western china. CPEC is a joint project of Pakistan and Chinese government agreed to finance through Chinese investments utilizing investment loans largely by Chinese institutions. Pakistan will also invest 15 billion dollars on its own in the process. Through this Pakistan's trade will increase, transportation will become more efficient, constructing energy projects to improve its energy situation This mega project will enhance regional connectivity, develop infrastructure and easy way to contact people to people in both countries
\end{abstract}

Keyword: CPEC, Infrastructure, Future, Challenges, Development, Transport.

\section{INTRODUCTION}

China Pakistan Economic Corridor (CPEC) is considered being the game changer not only for Pakistan but also for whole of South Asian region, Central Asia and Middle East. CPEC is the backbone of the economy of Pakistan. CPEC is mainly known as transport corridor and it is a greater opportunity for Pakistan to increase their employment and improve infrastructure and make trade easy and reliable. Pakistan China relation began in 1950,the relationship between both countries is based on strong strategic, economic and political foundation Hussain, 2016 stated that CPEC is a wide-ranging set of supportive projects and initiatives, which covers main areas including connectivity industrial parks and industries, agricultural development, information network infrastructure, energy cooperation, tourism, poverty alleviation, livelihood improvement including municipal infrastructure as well as financial corporation, public health, education, and people to people contacts by linking Kashgar with Gwadar through Gilgit-Baltistan and the other areas of Pakistan

In the era of Pakistan Muslim League Nawaz (PML-N), the development of many commercial infrastructures including the rapid transit services and motorways was started under the CPEC. Some of these projects are nearing their completion while some have been completed. Taking this project to new heights and improving the relations with an all-weather-friend China is part of ruling Pakistan Tehreek-e-Insaf's (PTI) manifesto. The seriousness of the government about its collaboration with its neighbour could be understood by the fact that 
when Prime Minister Imran Khan visited China, 15 new documents were signed regarding economic, cultural, and political collaboration between the two nations. The previous administrations focused on physical infrastructures but the new government is giving the Chinese corridor a new direction. It desires to use this project for educational, agricultural, and cultural reforms.

The new government blames the previous administrations for economic instability in the country. The Pakistan Tehreek-e-Insaf (PTI) criticized that the previous government borrowed Chinese money and invested it in the public sector for quick construction of roads to gain the maximum popularity and to enhance its vote bank. As a result, the economy started growing artificially.

Aside from this, the CPEC shifting toward business-to-business interaction, unlike an entirely government-based collaboration. Meaning many new private companies will take part in the schemes and the entrepreneurs will get a chance to manage the corridor. By doing this, the government hopes to create new jobs in the private sector. Furthermore, the authorities are also inviting other countries to invest in this venture and many agreements have been signed with different countries including Saudi Arabia in this regard.

\section{CPEC Progress and Prospects}

The China Pakistan Economic Corridor(CPEC), as a pilot venture of the "Belt and Road" Initiative, was authoritatively propelled in 2013. President Xi Jinping, during his visit to Pakistan in April 2015. Practices in the previous five years have demonstrated that the CPEC development isn't focusing on explicit areas or gatherings, yet is going for the entire nation of Pakistan and advantages every one of the general population of Pakistan.

CPEC has respected the easing of vitality lack in Pakistan as one of the significant territories of development since its dispatch. Right now, 12 ventures with a complete introduced limit of 7,240 MW have been started or put into task. Through five years of development, vitality extends under the CPEC system added 3,340 MW of power to Pakistan by early April 2019, representing $11 \%$ of the nation's absolute introduced power limit, in this manner extraordinarily easing the power lack in Pakistan. In mid 2019, CPEC incorporates 9 finished early collect ventures and 13 extends under development, with an all out speculation of US\$19 billion. It drove Pakistan's monetary development by one to two rate focuses each year and made 70,000 occupations in Pakistan. The Chinese government gave US $\$ 5.874$ billion in concessional advances to Pakistan, with a merged loan fee of just $2 \%$, far lower than the normal financing cost. Later on, the two nations are relied upon to consent to a progression of arrangements covering territories identified with individuals' expectations for everyday comforts, including training, wellbeing, horticulture, water for water system, destitution easing and HR improvement. Clinics have been set up in Khyber Pakhtunkhwa and Balochistan and professional and specialized preparing schools have been set up all through Pakistan.

Distribution of Investment in CPEC
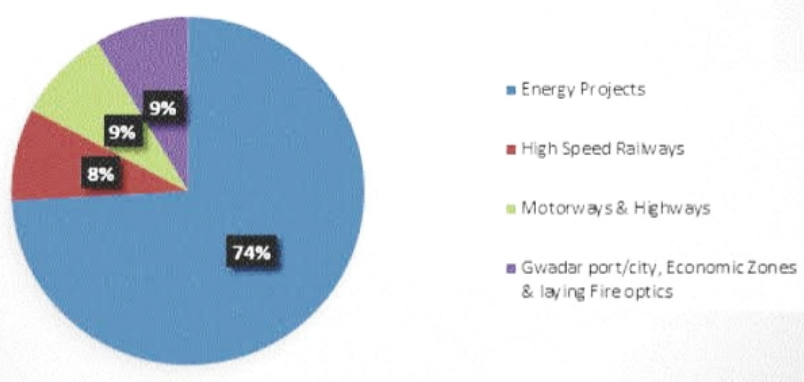


\section{CPEC Future Prospects}

After the general election's in 2018, there was a worry at home and abroad about whether Pakistan's mentality towards CPEC would change because of the difference in government. Around a similar time, there were some global sentiments addressing CPEC, saying that a lot of Chinese credits may brings Pakistan into obligation emergency. Nonetheless, certainties over the previous years have demonstrated that the assurance to assemble CPEC has not been shaken by the difference in government in Pakistan and the obligation emergency hypothesis has been destroyed. In advancing the CPEC development, China has dependably pursued the standards of meeting, commitment and shared advantages, and given top need to Pakistan's financial improvement and the imperative interests of the Pakistanis. In light of Pakistan's future financial and social advancement needs and individuals' needs, the future improvement way and participation heading of CPEC will be resolved through discussion, with need given to quickening collaboration in businesses, parks and horticulture, making occupations, and improving individuals' expectations for everyday comforts.

Pakistan and China reaffirmed their total agreement on the future direction of the ChinaPakistan Economic Corridor (CPEC), convenient finishing of its on-going undertakings. The two nations likewise restored the promise towards endeavoring joint endeavors for the acknowledgment of its maximum capacity, with an attention on financial advancement, work creation and jobs just as quickening participation in mechanical improvement, modern parks and agribusiness.

\section{CPEC Challenges}

China Pakistan Economic Corridor (CPEC) faces a few inner and outer difficulties, Dr. Luan Jianzhang ( Vice Director General of Policy Research ) is of the view that political distress, security circumstance and managerial issues are probably the best difficulties in the method for effective consummation of the passageway. Pakistan's economy is right now confronting budgetary emergency and its cash is falling step by step. Pakistan has a genuine monetary shortage, a tremendous outside obligation and an overwhelming obligation administration load. The ability to give supporting assets to the CPEC development has declined strongly and it is never again achievable to extend foundation development. Pakistan's new government needs to get control over colossal capital spending, particularly on tasks that require a lot of remote trade. Over three decades, Pakistan has occasionally gotten a handle on the finger of the International Monetary Fund (IMF) to stroll through the mud of financial insecurity. The experts keep up that none of the bailout programs by the IMF were effective in Pakistan. That is the reason the nation is as yet confronting budgetary difficulties

The general security circumstance in Pakistan has improved step by step, yet psychological oppressor assaults still happen much of the time. Over the previous year, rough and psychological oppressor assaults propelled by Baluchistan separatists happened as often as possible, with changes in structure, topographical development and new highlights, and the danger to Gwadar Port and CPEC has expanded. The mind boggling global political circumstance, particularly the obstruction of outer factors on CPEC, can't be disregarded. Another test is identified with the expert mastery to finish and empowering transport, correspondence frameworks that can encourage the consummation of the tasks on schedule.

\section{Determination to Build CPEC}

In November 2018, Pakistan's Prime Minister Imran Khan made his first official visit to China and went to the primary China International Import Expo in Shanghai. During his visit, the two nations achieved significant agreement and marked a joint proclamation on further fortifying the China-Pakistan all-climate vital helpful organization and building a closer China-Pakistan 
people group of shared future in the new time. Head administrator Imran Khan clarified that the finished ventures of CPEC are in light of a legitimate concern for Pakistan and will bring tremendous social and financial advancement chances to the Pakistani individuals. Since China has lifted in excess of 700 million individuals out of destitution in the previous decades, Pakistan is happy to gain from the Chinese government's neediness mitigation measures.

In addition, Pakistan is thinking about utilizing the Chinese cash for two-sided exchange. The two nations consented to work together in Pakistani rupee and Chinese cash Yuan during the visit of Prime Minister Imran Khan to Beijing. Before Chinese President Xi Jinping and PM Imran Khan, Turkish President Recep Tayyip Erdogan had propelled development to end the strength of dollar. China, Russia and Turkey had been battling against the matchless quality of dollar, anyway Pakistan joined the trio as of late.

As a huge and efficient venture, which spreads 2013-2030, CPEC needs joint and unremitting endeavors by governments, organizations and every single social part of China and Pakistan. During the time spent its development, the two sides concurred on the standards of logical arranging, well ordered execution, agreement through interview, shared advantage just as guaranteeing quality and safe.

\section{CRITICAL REVIEW}

The China Pakistan financial hallway is a Mega Multi-Dollar venture among China and Pakistan it is a more noteworthy open door for Pakistan to improve it economy and exchange, upgrade local availability, defeat vitality emergencies, create foundation and contact individuals in the two nations. CPEC brings greater business opportunity fore the general population of Pakistan.CPEC assumes a noteworthy job in Pakistan CEPC undertakings includes agribusiness use which will begin in Gilgit Baltistan to expand organic product generation. There will be expanded CPEC openings for work in the neighborliness and Restaurant industry because of the prerequisites of rest houses along the entire CPEC in this way will help lift up the economy, Pakistan will profit by obligations on outside exchange. CPEC is a huge scale activity to assemble vitality, Highway and Port framework to more profound financial association ,It will profit every one of the areas of Pakistan.

But they are not only positive impacts of CPEC there are also negative impacts. Some questions are also rise in mind.

1) what is the interest percentage that Pakistan have to return?

2) what is Monthly pay back loan?

3) on which USD rates Pakistani return its interest and loan?

4) All the investment is incurred by China then how much profit will be distributed to Pakistan?

5) what is time period of loan payable?

6) why China investing in Dollars why not in yuan?

The rate of USD is increasing due to economic instability the interest and loan is increasing.This corridor will completed in 2030 and China is investing all the money so when the loan is not fully paid the maximum profit will be given to China under this plan thousands of areas of agriculture land will be leased out to Chinese enterprises Pakistan's dependence on china will increase due to dept repayments.

\section{CONCLUSION}

Being a developmental project, CPEC has countless benefits to Pakistan as it was going through a tough time where Pakistan is suffering from many crises e.g political energy, social financial 
etc. There may so many costs of the project but there were no other option to opt for. From one viewpoint it give financial advantages while then again it additionally reinforce the connection among China and Pakistan. china Pakistan financial hall will construct stable economy in Pakistan and will make a critical open door for Pakistan to restore its industry and advance its monetary intrigue. CPEC is a distinct advantage venture which will lift million of Pakistanis out of destitution and hopelessness.

\section{References:}

http://dspace.khazar.org/handle/20.500.12323/4029

http://pu.edu.pk/images/journal/pols/pdf-files/14 25 2 18.pdf

http://pakistanhouse.net/wp-content/uploads/2016/11/CPEC-challenges.pdf

http://www.gssrjournal.com/jadmin/Auther/31rvIolA2LALJouq9hkR/9cTysXma9h.pdf

https://www.think-asia.org/handle/11540/9583

http://www.issi.org.pk/wp-content/uploads/2015/12/Moonis-Ahmar_3435_SS_41_20142015.pdf

https://www.osti.gov/biblio/1344537

https://www.ssoar.info/ssoar/handle/document/46898

https://ideas.repec.org/a/ibn/ibrjnl/v10y2017i8p204-214.html

https://iopscience.iop.org/article/10.1088/1757-899X/414/1/012046/meta

https://www.google.com/url?sa=t\&rct=i\&q=\&esrc=s\&source=web\&cd=3\&cad=rja\&uact=8\&ved=2ahUKEwiChoS XheniAhUF3xoKHVG4DDIQFjACegQIBBAB\&url=http\%3A\%2F\%2Fblogs.dunyanews.tv\%2F23961\%2F\&usg=AOv Vaw1s8xUka0U7X0dy85ycVf-E

https://www.google.com/url?sa=t\&rct=j\&q=\&esrc=s\&source=web\&cd=1\&ved=2ahUKEwj72LfSheniAhWwxoUK HQfeAZIQFjAAegQIBhAC\&url=http\%3A\%2F\%2Fcpec.gov.pk\%2F\&usg=AOvVaw3-5TNAo_mApiTkIXLBH6-e 